\title{
Use of Live Varicella Vaccine in Childen with Acute Leukemia
}

\author{
Hiroshi Nakagawa and Noriko Katsushima* \\ Department of Pediatrics, Iwaki-Kyoritsu General Hospital, \\ Iwaki 973 and *Department of Pediatrics, Yamagata City \\ Hospital, Yamagata 990
}

\begin{abstract}
Nakagawa, H. and Katsushima, N. Use of Live Varicella Vaccine in Children with Acute Leukemia. Tohoku J. exp. Med., 1978, 126 (4), 393-395 - Seven children with acute leukemia were given a live attenuated varicella vaccine and successfully seroconverted with minimal clinical reactions. One of them was vaccinated immediately after the contact with natural varicella and successfully prevented from natural infection. _ live varicella vaccine; leukemia
\end{abstract}

It is well known that chickenpox is severe and frequently fatal in children with malignancies and receiving chemotherapy (Rifkind 1966).

In 1977, Izawa et al. reported successful prevention of natural varicella after vaccination using live varicella vaccine of Takahashi et al. $(1974,1975)$ in leukemic children, that is, three of the vaccinees were exposed to natural varicella 2 to 18 months after vaccination, but they were free from any varicella symptoms.

In the present study, we vaccinated the live varicella vaccine of Takahashi et al. $(1974,1975)$ to 8 children with leukemia, and all of them became seropositive for the neutralization test 2 to 6 weeks after the vaccination, and the positive skin reaction with varicella antigen was found in 5 children tested.

One of the patients (Case 7) was vaccinated immediately after close contact with a natural varicella patient in the ward, but she showed no clinical symptoms of natural varicella except for rash which appeared 16 days after the vaccination.

\section{SubJects AND Methods}

Eight children with acute lymphocytic leukemia were all in remission for 24 months or less. Maintenance therapy was composed of 6 -mercaptopurine $(2-3 \mathrm{mg} / \mathrm{kg} / \mathrm{day}$ orally) and methotrexate $(2-3 \mathrm{mg} / \mathrm{kg}$ intravenously every two weeks). Methotrexate was suspended for 2 weeks after the vaccination. No abnormality was found in immunoglobulin levels of the serum (Table 1).

The live attenuated varicella vaccine used was the Oka strain of varicella virus (Takahashi et al. 1974, 1975).

The virus doses were 500 to 3,000 plaque forming units: $0.5 \mathrm{ml}$ of the vaccine was injected subcutaneously into each patient. The neutralization test $(\mathrm{N}$ - $\mathrm{T})$ for the antibody was carried out in the same way as described by Izawa et al. (1977).

In the skin test with varicella virus, $0.1 \mathrm{ml}$ of viral antigen was injected intracutaneously on the forearm and skin reaction was measured $48 \mathrm{hr}$ later. The erythematous change

Received for publication, June 2, 1978. 
$5 \mathrm{~mm}$ or greater in diameter was determined to be the positive reaction (Kamiya et al. 1977).

TABLE 1. Checkup of patients before vaccination

\begin{tabular}{|c|c|c|c|c|c|c|c|c|}
\hline \multirow{2}{*}{$\begin{array}{l}\text { Case } \\
\text { No. }\end{array}$} & \multirow{2}{*}{$\begin{array}{l}\text { Age/sex } \\
\text { (years) }\end{array}$} & \multirow{2}{*}{$\begin{array}{c}\mathrm{Hb} \\
(\mathrm{g} / 100 \mathrm{ml})\end{array}$} & \multirow{2}{*}{$\begin{array}{c}\text { Platelets } \\
\left(\times 10^{4} / \mathrm{mm}^{3}\right)\end{array}$} & \multirow{2}{*}{$\begin{array}{c}\text { WBC } \\
\left(/ \mathrm{mm}^{3}\right)\end{array}$} & \multirow{2}{*}{$\begin{array}{c}\text { Lymphocytes } \\
(\%)\end{array}$} & \multicolumn{3}{|c|}{$\begin{array}{l}\text { Serum immunoglobulins } \\
(\mathrm{mg} / 100 \mathrm{ml})\end{array}$} \\
\hline & & & & & & $\operatorname{Ig} A$ & IgM & IgG \\
\hline 1 & $7 / \mathbf{F}$ & 11.0 & 30.4 & 6,200 & 51 & 72 & 82 & 1,000 \\
\hline 2 & $7 / \mathrm{M}$ & 14.0 & 33.1 & 8,800 & 52 & 70 & 64 & 820 \\
\hline 3 & $3 / \mathrm{M}$ & 10.0 & 18.4 & 4,100 & 67 & 75 & 110 & 670 \\
\hline 4 & $2 / \mathrm{F}$ & 14.0 & 31.1 & 4,000 & 60 & 110 & 140 & 1,050 \\
\hline 5 & $2 / \mathrm{M}$ & 9.4 & 13.3 & 2.900 & 62 & 75 & 110 & 670 \\
\hline 6 & $3 / \mathrm{F}$ & 10.4 & 26.4 & 5,400 & 75 & 63 & 130 & 1,700 \\
\hline 7 & $2 / \mathrm{F}$ & 10.1 & $<0.3$ & 1,400 & 94 & 75 & 50 & 1,182 \\
\hline 8 & $3 / F$ & 10.6 & 14.3 & 3,300 & 51 & 182 & 130 & 1,350 \\
\hline
\end{tabular}

\section{Results and Discussion}

No clinical symptoms were observed in 8 children subjected to the vaccination, except for 3 (Cases 5, 7 and 8), in which Cases 5 and 7 were receiving corticosteroid at the time of vaccination.

In Case 5, three vesicles were observed on his face and head on the 25th day of vaccination, then they increased in number up to 20 , but they turned to crusts within a few days. He was clinically well except for intermittent low grade fever of $37.4^{\circ} \mathrm{C}$

In Case 7, she was exposd to a patient with natural varicella in the ward. She was given the live varicella vaccine within $6 \mathrm{hr}$ after the contact. On the 16th day of vaccination, a few vesicles and papules developed, but she was well otherwise during her stay in the hospital.

Case 8 was vaccinated in a larger dose of 3,000 plaque forming units. On the 18th day following vaccination about forty vesicles appeared on the whole body and she was febrile for 2 successive days, but her general condition was kept well.

TABLE 2. Clinical reaction, antibody response and skin test reaction

\begin{tabular}{|c|c|c|c|c|c|c|c|c|}
\hline \multirow{2}{*}{$\begin{array}{l}\text { Case } \\
\text { No. }\end{array}$} & \multirow{2}{*}{$\begin{array}{c}\text { Time after remission } \\
\text { at vaccination } \\
\text { (months) }\end{array}$} & \multirow{2}{*}{$\begin{array}{l}\text { Virus dose } \\
\quad(\mathrm{PFU})\end{array}$} & \multirow{2}{*}{$\begin{array}{l}\text { Clinical } \\
\text { reaction }\end{array}$} & \multicolumn{4}{|c|}{ Antibody response* } & \multirow{2}{*}{$\begin{array}{l}\text { Skin } \\
\text { reaction } \dagger \\
(\mathrm{mm})\end{array}$} \\
\hline & & & & Before & 4 wk & $6 \mathrm{wk}$ & 3 mon & \\
\hline 1 & 24 & 500 & - & $<2$ & 2 & 2 & 8 & $10 \times 10$ \\
\hline 2 & 18 & 500 & - & $<2$ & 2 & 4 & 4 & $27 \times 26$ \\
\hline 3 & 15 & 500 & - & $<2$ & 2 & 2 & 2 & $12 \times 12$ \\
\hline 4 & 11 & 500 & - & $<2$ & 2 & 4 & 8 & $18 \times 17$ \\
\hline 5 & 3 & 500 & Rash & $<2$ & 8 & 32 & 8 & $16 \times 16$ \\
\hline 6 & 15 & 1,000 & - & $<2$ & $8(2 w \mathbf{k})$ & & n.d. & n.d. \\
\hline 7 & 1 & 1,000 & Rash & $<2$ & n.d. & 4 & n.d. & n.d. \\
\hline 8 & 4 & 3,000 & Rash & $<2$ & 8 & n.d. & n.d. & n.d. \\
\hline
\end{tabular}

* Reciprocal titer of NT antibody.

$\dagger$ Skin test with varicella virus antigen. Before, before vaccination; n.d., not done; PFU, plaque forming unit. 
In this respect, it is worthy of note that Asano et al. (1977) reported that household contacts were protected from varicella infection when they received vaccine within $72 \mathrm{hr}$ after exposure.

All the children subjected to our study were seroconverted 2 to 6 weeks after the vaccination, and positive skin test was observed in 5 children tested (Table 2).

\section{Acknowledǵment}

We gratefully acknowledge Associate Professor Michiaki Takahashi, the Research Institute for Microbial Diseases, Osaka University, for providing us live varicella vaccine, and Professor emeritus Tsuneo Arakawa, the Department of Pediatries, Tohoku University School of Medicine, for his advice in preparing this manuseript.

\section{References}

1) Asano, Y., Nakayama, H., Yazaki, T., Kato, R., Hirose, S., Tsuzuki, K., Ito, S., Isomura, S. \& Takahashi, M. (1977) Protection against varicella in family contacts by immediate inoculation with live varicella vaccine. Pediatrics, 59, 3-7.

2) Izawa, T., Ihara, T., Hattori, A., Iwasa, T., Kamiya, H., Sakurai, M. \& Takahashi, M. (1977) Application of a live varicella vaccine in children with acute leukemia or other malignant diseases. Pediatrics, 60, 805-809.

3) Kamiya, H., Ihara, T., Hattori, A., Iwasa, T., Sakurai, M., Izawa, T. \& Yamada, A. (1977) Diagnostic skin test reactions with varicella virus antigen and clinical applications of the test. J. infect. Dis., 136, 784-788.

4) Rifkind, D. (1966) The activation of varicella-zoster virus infections by immunosuppressive therapy. J. Lab. clin. Med., 68, 463-474.

5) Takahashi, M., Otsuka, T., Okuno, Y., Asano, Y., Yazaki, T. \& Isomura, S. (1974) Live vaccine used to prevent the spread of varicella in children in hospital. Lancet, 2, 1288-1290.

6) Takahashi, M., Okuno, Y., Otsuka, T., Osame, J., Takamizawa, A., Sasada, T. \& Kubo, T. (1975) Development of a live attenuated varicella vaccine. Biken $J$., 18, $25-33$. 